\title{
Relationship between the demographic characteristics of park users and intensity of park use: the case of Stanley Park and Queen Elizabeth Park
}

\author{
Stephen Appiah Takyi \\ Kwame Nkrumah University of Science and Technology, Ghana \\ drtakyi410@gmail.com
}

\author{
Andrew D. Seidel \\ University of Northern British Columbia, Canada \\ adseidel88@gmail.com
}

Jones Kweku Adjei

Red Deer College, Canada

jones.adjei@rdc.ab.ca

\begin{abstract}
Parks are among the few urban infrastructure that functionally combines all the three pillars of sustainable development namely: ecological, social and economic functions. For example, Stanley Park currently serves as one of the largest tourist destinations in Canada. This helps to promote economic growth through the money spent by tourists in the City of Vancouver. The park also provides ecological services through its green infrastructure whilst at the same time serving as a place for social activities such as cycling, jogging and playing tennis. Despite the enormous benefits derived from urban parks, there is a paucity of research investigating the individual demographic characteristics that tend to associate with increased utilization of public parks within an urban setting. There is therefore the need for park researchers and administrators to understand the relationship between the demographic characteristics of park visitors and intensity of park use. The data used for this research was collected through a survey conducted at Stanley Park and Queen Elizabeth Park, both located in Vancouver, British Columbia, Canada.. Chi-square tests were used to assess the association between individual demographic characteristics and increased utilization of public parks. For Stanley Park, place of origin and age were the most important predictors for high park patronage; while employment status and sex were found to be the significant factors that associated with high intensity use of Queen Elizabeth Park. The study shows that different demographic variables influence the intensity in the utilization of Stanley Park and Queen Elizabeth Park. Park administrators and policy makers must therefore undertake park specific needs assessment when providing park facilities, programs and services. This will help promote effective and efficient park service delivery.
\end{abstract}

Keywords: park planning, demographic characteristics, intensity, park use

To cite this article:

Appiah Takyi, S., Siedel, A. D., Kweku Adjei, J. (20I8). Relationship between the demographic characteristics of park users and intensity of park use: the case of Stanley Park and Queen Elizabeth Park. The Journal of Public Space, 3(3), 49-74, DOI 10.3289I/jps.v3i3.II 36

This article has been double blind peer reviewed and accepted for publication in The Journal of Public Space.

This work is licensed under a Creative Commons Attribution - Non Commercial 4.0 International License https://creativecommons.org/licenses/by-nc/4.0/ 


\section{Background of the study}

Historically, parks were created to address specific urban planning problems by helping to restore some elements of the country in cities (Takyi, 2016). Sadeghian and Vardanyan (20I5) describe a park as "an area of natural, semi-natural, or planted space set aside for human enjoyment and recreation or for the protection of wildlife or natural habitats" ( $p$. 120). The contemporary roles of parks have moved beyond its ecological functions to include economic and social functions. The multi-functional roles of parks have therefore necessitated the need not to restrict the provision of park facilities to only urban areas. Park services such as recreational and tourism facilities are currently being provided in the both the town and country

The level of investments in the development of parks continue to increase. This is because of the environmental, social and economic benefits of parks. According to Chiesura (2003), the development of urban green spaces provides economic, environmental, ecological, social and psychological benefits. The need to preserve the natural character of cities for example, has increased public interest in the development of eco-friendly cities (Takyi \& Seidel, 20I7). Environmentally friendly cities generate tourist attractions, provide a favorable environment for active living and also promote the health of their inhabitants. These factors are currently serving as pull factors for people to live in such healthy communities, leading to the economic vibrancy of these cities. This shows a strong relationship between the sustainable environmental management of cities and their economic vibrancy.

Despite the enormous benefits derived from the use of urban parks, there is limited research in the area of assessing the relationship between the demographic characteristics of park users and intensity of park use. This neglect is unfortunate because there is evidence that knowledge of park user characteristics is useful in differentiating, segmenting and targeting park visitors according to various categories of activities (McCormark 20I0; Mowen et al. 20I2). This situation poses challenges to recreation and park agencies that wish to address the diversified leisure needs and preferences of park users (Payne et al., 2002).

A better understanding of how demographics, behaviour and experience preferences correspond to different physical activities helps in the development of a focused program, facilities and promotional efforts to increase park based activity levels (Mowen et al., 20I2).

The few studies assessing the relationship between park user characteristics and park use have not however yielded consistent results. Field (2000) found that time and space are important variables that help in explaining the regularity of social behaviour in parks. Scott (1997), on the other hand, indicated that there is as an association between the activities of park users and the time of the day, day of the week and season of the year. Other studies noted the effect of some demographic factors such as race (see e.g., Gobster 2002; Payne et al. 2002) and age (see e.g., Kemperman and Timmermans 2005) on park use behaviour.

The overall goal of the study is to analyse how the demographic characteristics of park users influence park use and management through an assessment of the relationship between the demographic characteristics of park users and intensity of park use within the context of a cosmopolitan urban setting of Vancouver City. 


\section{Study sites}

The City of Vancouver in the province of British Columbia, Canada, was selected as the study site on the basis of its long standing position as a nodal point for both internal and transnational flow of goods and people (Horak \& Young, 20I2). The City of Vancouver is currently noted for its ambitious plan to become the world's most sustainable city through the formulation of policies to protect its natural environment including its green spaces. According to Horak and Young (20I2), the City of Vancouver has consistently been ranked among the growth leaders within the Canadian urban system since the deep recessions in the 1980s. The city's urban parks give a broader view on the study of parks due to their social, environmental and economic characteristics and benefits.

The City of Vancouver has a population of 603,502 with a population density of 5,249.I people per square kilometre (Statistics Canada, 20I2). It is one of the most diverse cities in the world thus making it a single case study with diverse socio-economic characteristics. According to Statistics Canada (2008), the percentage of immigrants to the total population increased from $44.4 \%$ in 1996 to $45.1 \%$ in 2006 . The high percentage of immigrants in the city has contributed to its diverse demographic characteristics. The city also offers an important case for studying the operation and management of its variety of city parks from both historical and contemporary perspectives. The research focused on the two major parks in the City of Vancouver namely Stanley Park and Queen Elizabeth Park. Stanley Park which was created in 1888 is a 400 hectare park located in the City of Vancouver. The park is a good representation of large urban parks with tourism potential. Stanley Park has diversified elements of natural and cultural environments.

Queen Elizabeth Park is a 52 hectare park developed in 1930. This park effectively combines the social, ecological and economic functions of parks. The findings of the study are applicable to cities with similar situations and characteristics as the City of Vancouver. Also, park administrators of large and medium size parks such as Stanley Park and Queen Elizabeth Park can rely on some of the findings of the study for effective and efficient park management. The brief description and justification for selecting each of the parks have been presented in Table I.

Table I-Description of Selected Parks and Justification of Choice Source: Vancouver Park Board

\begin{tabular}{c|l|l|l}
\hline Name of park & Year of establishment & Brief description & Justification of choice \\
\hline Stanley Park & 1888 & $\begin{array}{l}\text { - Diversified elements of } \\
\text { natural and cultural } \\
\text { environments. } \\
- \text { A 400-hectare natural } \\
\text { West Coast rainforest. }\end{array}$ & $\begin{array}{l}\text { - National Historic Site } \\
\text { - Vancouver's first and largest } \\
\text { park }\end{array}$ \\
\hline
\end{tabular}




\begin{tabular}{|c|c|c|c|}
\hline $\begin{array}{l}\text { Queen } \\
\text { Elizabeth Park }\end{array}$ & 1930 & $\begin{array}{l}\text { - Vancouver's } \\
\text { horticultural jewel and } \\
\text { the city's highest point at } \\
\text { I52 metres above sea } \\
\text { level. } \\
\text { - A } 52 \text {-hectare park and } \\
\text { home to the stunning } \\
\text { Bloedel Conservatory. }\end{array}$ & $\begin{array}{l}\text { - Combines social, ecological and } \\
\text { economic functions of parks. } \\
\text { - Diverse range of recreation } \\
\text { including golf, tennis, lawn } \\
\text { bowling and disc golf. } \\
\text { - Good representation for the } \\
\text { study of medium size Parks in } \\
\text { cities with similar characteristics } \\
\text { like the city of Vancouver. }\end{array}$ \\
\hline
\end{tabular}

\section{Research method}

The study was conducted using a structured interview with a total sample size of 725 respondents (374 interviewed at Stanley Park and 35I interviewed at Queen Elizabeth Park). The general sampling strategy for the park user survey relied on the application of certain aspects of the stratified sampling technique, where the various parks were divided into strata based on the various categories of uses. This served as the basis for distributing the questionnaires to potential research participants.

Stratified sampling is frequently useful to divide the population into subgroups called strata (Sudman, 1976). As already discussed, the case study for this research is the City of Vancouver in Canada. Within the City of Vancouver, the study areas selected are Stanley Park and Queen Elizabeth Park.

Questionnaires were distributed among users of Stanley Park based on the six areas of attractions, the fifteen activity areas, the four restaurants and the four sports clubs. The map of Stanley Park showing the various activity areas has been presented in Figure I. Questionnaires administered at Queen Elizabeth Park were also distributed among the users of Bloedel Conservatory, Seasons Restaurant, Rose Garden, Tennis Courts, Pitch \& Putt Golf and a Celebration Pavilion. These activity areas have been presented in Figure 2. The systematic sampling technique was used in selecting interview respondents. A systematic sampling technique is used far more frequently than simple random sampling because of its simplicity and usefulness in complex sampling situations (Sudman, 1976). The two main things used for systematic sampling technique according to Sudman (1976) were the sampling interval and a random start. The interviewers of this study chose the first park user to be met who was older than 17 years as the random start and the sampling interval was 3 that is, each $3^{\text {rd }}$ person after the interviewed person will be selected.

This strategy was however, not applicable to park users involved in active recreation and areas within the parks with less number of people. Park users involved in active recreation such as biking and jogging were automatically selected once the user agreed to participate in the study and were more than 17 years of age. The analysis of the park user characteristics specifically dealt with the demographic characteristics of the park users which include the gender of the users, their employment status, age and income. 


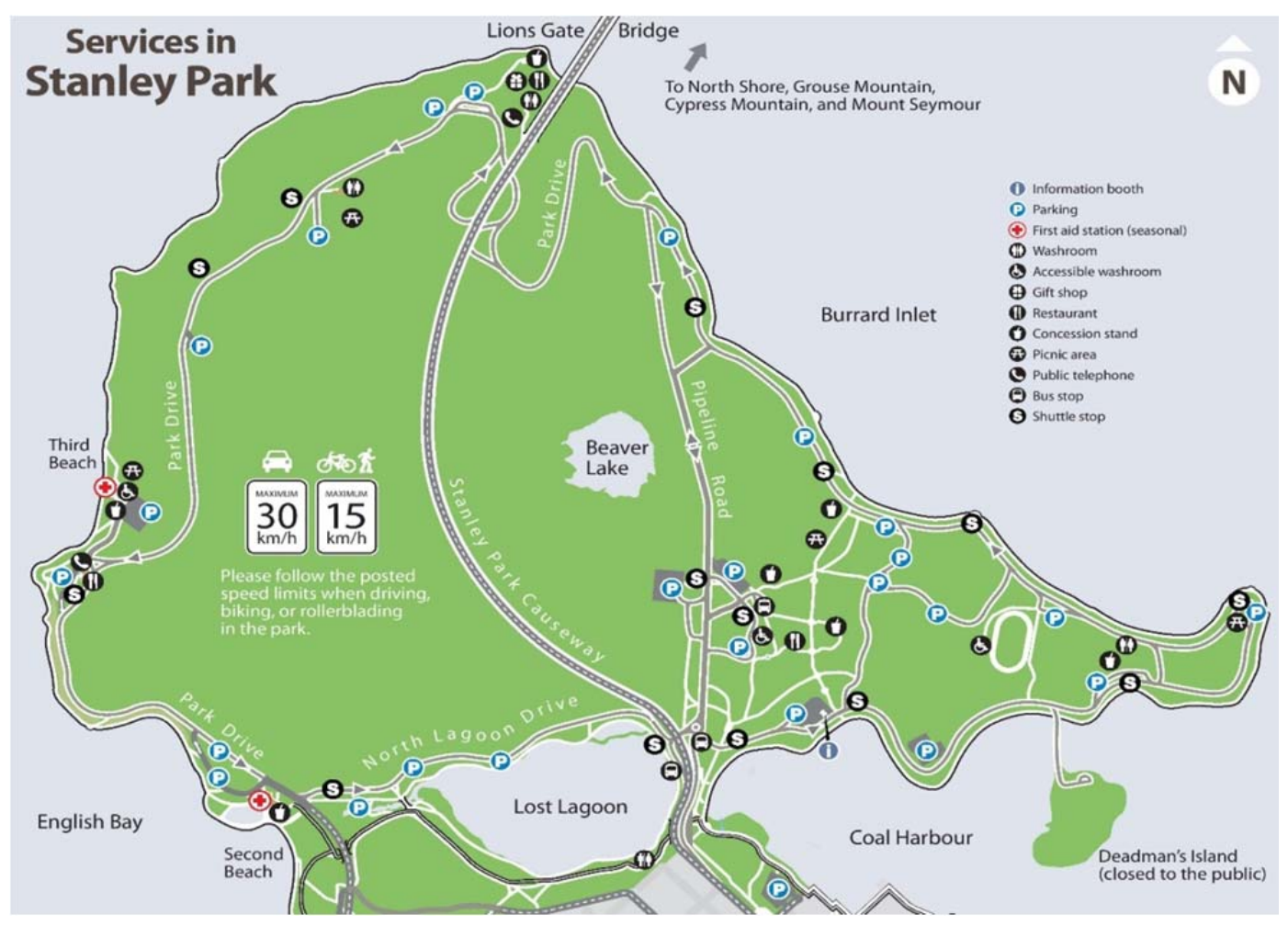

Figure I. Map of Stanley Park Showing the Various Activity Areas. Source: City of Vancouver Park Boards.

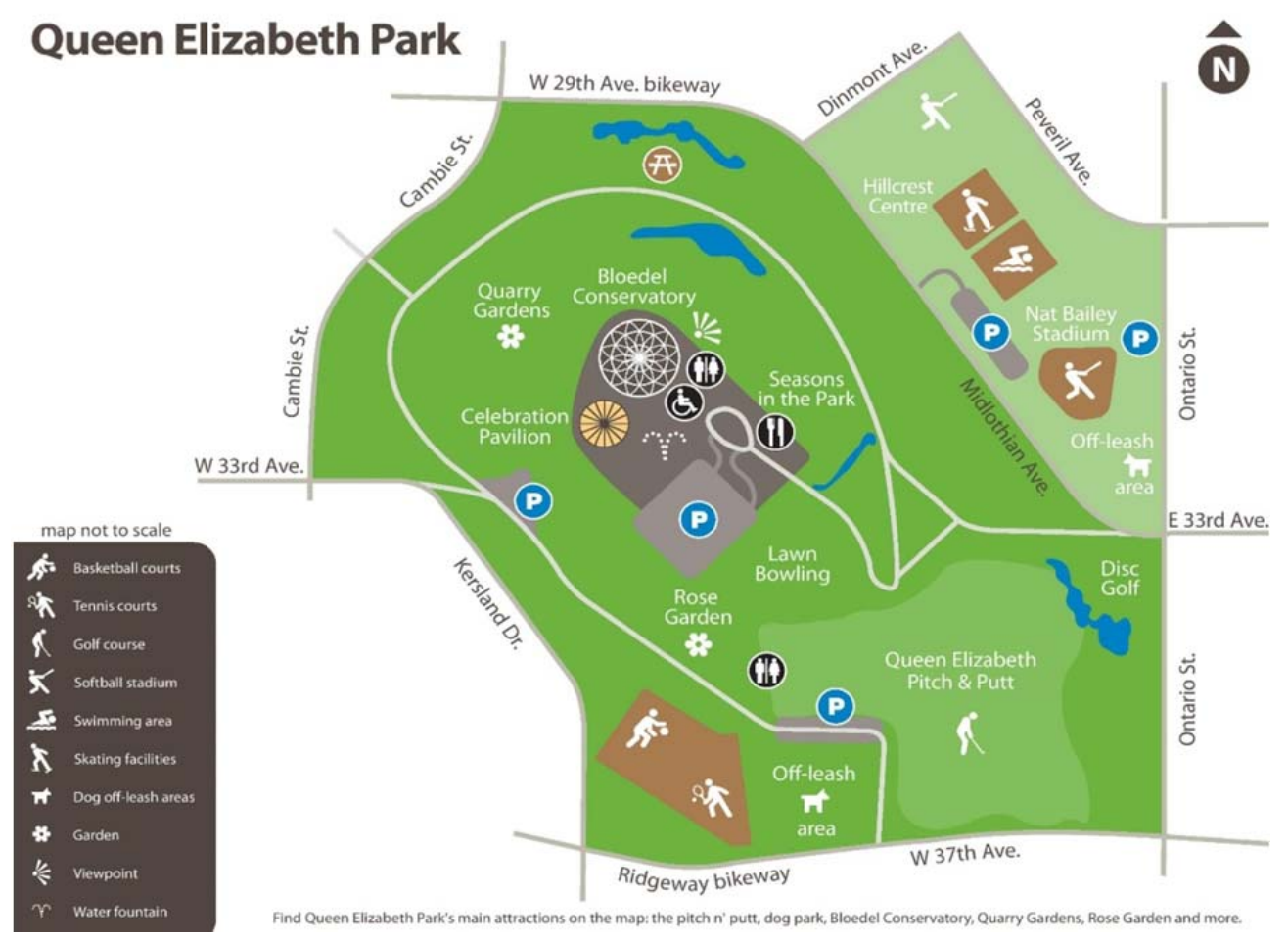

Figure 2. Map of Queen Elizabeth Park Show Activity Areas Source: City of Vancouver Parks Board 


\section{I Measures and analysis}

The structured questionnaire used for the survey consisted of 26 questions. The questions covered major themes such as the demographic characteristics of park users, park use information, park management and information on park activities. These themes served as the basis for data categorization. A code book containing the question number, the name of the variable, the question, and the code was created. During the coding, numbers were used to represent response categories. With regards to binary response categories, zero and one were used to code the variables.

Data entry, analysis and statistical tests were done using Microsoft excel and Strata software (version 12) were used for the analysis of data and the various statistical tests. The relationship between the demographic characteristics of park users and intensity of park use was tested using the chi-square analysis. The $p$-values were calculated and the significance level is established at the 0.05 alpha level. Generally, $p$-values less than 0.05 provide evidence of significant association between a particular demographic factor and intensity of park use.

\section{Results of the study}

\section{I Age of park users}

The age structure helped in understanding the statistical components of the different age groups of Stanley Park and Queen Elizabeth Park. This will serve as an important basis for informing decision makers on the age specific needs of the various visitors of the parks. Overall, majority of the park users for both parks comprised of mostly a youthful population. The survey in Stanley Park showed that $41.67 \%$ of park visitors were in the age cohorts of $18-34,32.26 \%$ in the cohort of $35-49,16.13 \%$ in the cohort of $50-64$ and $9.95 \%$ in the age cohort of 65+. On the other hand, the survey in Queen Elizabeth Park indicated that $48.43 \%$ of the survey respondents were in the age cohort of $18-34,25.64 \%$ in the cohort of $35-49,17.09 \%$ in the cohort of $50-64$ and $8.83 \%$ in the cohort of $65+$. The use of Stanley Park and Queen Elizabeth Park are dominated by the youthful population because of the presence of a variety of active recreational facilities and activities on both parks. This notwithstanding, there is a fair number of park users who fall within the age cohorts of seniors. Although the proportion is small, the survey results showed that $9.95 \%$ of the respondents in Stanley Park fell within the retirement age while 8.83\% of the park users at Queen Elizabeth Park were seniors.

Generally, the results of this survey are consistent with already existing literature on the age structure of park users. Mowen et al. (20I2) for example found that older adults are less active than younger adults therefore they have a lower tendency to dominate in the use of parks. Cohen et al. (2007) survey on neighbourhood parks in the City of Los Angeles also showed few seniors using the parks in the city. However, their finding further showed that the presence of senior citizen centers on the park served as an attractive force for more seniors. The City of Vancouver Park Board can therefore, consider developing facilities such as the senior citizen centres which will stimulate park use among seniors. The minimum and maximum age of the users of Stanley Park was between 18 years and 89 years respectively. The most commonly occurring age among Stanley Park users was 32 years. Also, the average age for the visitors of Stanley Park was 
40.20 years thus indicating that the park users comprised of predominantly a youthful population.

It must however be noted that the minimum age of both Stanley Park and Queen Elizabeth Park was 18 years because the study did not include minors. Therefore, the minimum age required for participants to take part in the study was 18 years. The maximum age for Queen Elizabeth Park users was 84 years with the most commonly occurring age among the park users being 26 years. On average, the visitors of Queen Elizabeth Park were 39.I years of age. The analysis of the age distribution for Stanley Park and Queen Elizabeth Park users has been shown in Table 2.

Table 2. Demographic characteristics of park users.

Source: Stanley Park and Queen Elizabeth Park survey, 2014.

Age

18-34

$35-49$

50-64

$65+$

\section{Employment}

Full Time Employed

Part Time Employed

Seasonally Employed

Student

Unemployed

Voluntary Employed

Retired

Marital status

Married

Single

Divorced

Widowed

Gender

Male

Female

Other

Place of origin

Vancouver

Metro Vancouver

Within British Columbia

Within Canada

Outside Canada

\section{Stanley Park \% Queen Elizabeth Park\%}

$\begin{array}{rr}41.67 & 48.43 \\ 32.26 & 25.64 \\ 16.13 & 17.09 \\ 9.95 & 8.83\end{array}$

55.58

47.47

9.35

11.73

2.08

0.56

15.32

19.83

4.68

3.91

3.12

5.03

9.87

II.45

53.46

43.87

41.00

50.7 I

2.49

3.05

I. 42

49.73

51.85

48.40

47.29

$\mathrm{I} .87$

0.85

29.87

68.95

12.00

II. 4

7.20

5.13

16.00

5.41

34.93
9.12 


\begin{tabular}{lrr} 
Race/ethnicity & & \\
White & 66.49 & 53.56 \\
African & 1.61 & 1.99 \\
Native & 1.34 & 1.42 \\
Asian & 21.72 & 34.47 \\
Latino & 6.43 & 5.41 \\
Multi-Racial & 2.41 & 3.13 \\
Income & & \\
Less than 15,000 & 8.49 & 9.12 \\
I5,000-25,000 & 7.16 & 10.545 \\
25,000-50,000 & 17.24 & 21.37 \\
$50,000-75,000$ & 16.45 & 17.38 \\
$75,000-100,000$ & 17.77 & 17.38 \\
More than 100,000 & 32.89 & 24.22 \\
\hline \hline
\end{tabular}

\subsection{Gender of park users}

Arnold and Shinew (1998) argue that women are among one of the disadvantaged when it comes to the use of park and other leisure facilities. Kaczynski et al. (20II) supports this argument by indicating that women are generally more constrained than men in their leisure due to factors such as fear of crime. According to Henderson et al. (1996), some of the constraints to women's participation in leisure include busy work and domestic schedules and fear of violence. This theoretical analysis justifies why gender is an important factor in the use and management of parks. There is therefore the need for further studies to identify some of the factors that hinder or promote gender equality in the use of parks.

The results of the survey indicated that on the average more males use parks than females and the females that use the parks are normally accompanied by their male counterparts. According to the results, majority of the users of Stanley Park (49.73\%) were males, $48.4 \%$ were females while $1.87 \%$ were transgender. Similar to Stanley Park, Queen Elizabeth Park had more males using the park than females. The results of the survey indicate that park users who were males comprised of about $51.83 \%$ while $47.30 \%$ were females. Those who identified themselves as transgender constituted $0.85 \%$. Generally, the survey result for both Stanley Park and Queen Elizabeth Park did not deviate from some of the already existing studies on the analysis of gender and the use of parks. Mowen et al. (2012) for example argues that women are less active than men thus there is the tendency for men to dominate in the use of parks. A study conducted by Cohen et al. (2007) in the City of Los Angeles also showed that more males were using parks than females (62.00\% versus $38.00 \%)$. However, a lower proportion of females use parks in Los Angeles compared to that of the City of Vancouver. This could be attributed to the higher level safety issues in Los Angeles than the City of Vancouver.

\subsection{Employment status of park users}

Park researchers such as Kelly (1987) generally believe that there is a positive association between higher occupational statuses and leisure participation. The research findings 
showed a high employment rate among the visitors of both Stanley Park and Queen Elizabeth Park thus justifying this theoretical standpoint. According to Statistics Canada (20I5), the unemployment rate for the City of Vancouver in 2014 was $5.20 \%$ and that of 2015 is $4.80 \%$. Generally, the unemployment rate for City of Vancouver in 2014 and 2015 is higher than the unemployment rate for users of Stanley Park (4.68\%) and Queen Elizabeth Park (3.91\%). The study further showed that more than half of the survey respondents at Stanley Park are employed.

Historically, the working class were among the main target users for the development parks in the United States. According to Burdge (1969), individuals with higher occupational status have the greatest variety of leisure activities. This positively contributes to increasing their overall park use. The results of this study show the same trends but in this case, parks are not purposely developed for the working class but rather also influenced by issues of affordability.

The results showed that $55.58 \%$ of the survey respondents at Stanley Park were full time employed while $4.68 \%$ were unemployed. Also, the survey results indicated that the number of Stanley Park users who were part time employed were $9.35 \%$ while those who were seasonally employed constituted $2.08 \%$. Furthermore, park users who were students, voluntarily unemployed and retired at Stanley Park constituted I5.32\%, 3.12\% and $9.87 \%$ respectively.

On the other hand, the employment and unemployment rates among the users of Queen Elizabeth Park were $47.48 \%$ and $3.91 \%$ respectively. The survey results further indicated that Queen Elizabeth Park users who were employed on part time and seasonal basis were $11.73 \%$ and $0.56 \%$ respectively. Also, visitors of Queen Elizabeth Park who were students, voluntarily unemployed and retired comprised of $19.83 \%, 5.02 \%$ and $11.45 \%$ respectively.

\subsection{Race/ethnicity of park users}

Ballard (2006) describes the term race from two main perspectives. Race according to Ballard (2006) can be used to highlight the common genetic characteristics of the entire human kind. In the second description of race which applies to this study, Ballard (2006) define race as the categorical differences between different sub-sections of Homo sapiens such European Race or White Race.

Anold and Shinew (1998) note that minority ethnic groups such as Blacks are among the disadvantaged categories of people in the United States thus adversely affecting their level of leisure participation. Kaczynski et al. (20I I) also found that a greater percentage of Whites are active park users than other racial groups such as Blacks. There is the need for researchers and park managers to understand some of the factors that promote or inhibit racial equitability in the use of parks. This can be examined through an analysis of the racial/ethnic origin of park users.

The survey which did not contradict some of the already existing literature on park use and race showed that most of the tourists who visited Stanley Park for instance came from Europe thus contributing to the high percentage of Whites. The results further indicated that the percentage of Whites in Stanley Park was 66.49\%. Blacks and Aboriginal population on the other hand, consisted of $1.61 \%$ and $1.34 \%$. Furthermore, Stanley Park users who identified themselves as Asians, Latinos and Multi-Racials constituted $21.72 \%$, $6.43 \%$ and $2.41 \%$ respectively. 
The racial trends of neighbourhood parks normally reflect the overall racial characteristics of the city in which these parks are located. There were more Asians in Queen Elizabeth Park than in Stanley Park because Queen Elizabeth Park is mostly used by the residents of the City of Vancouver unlike Stanley Park which is dominated by tourists. The high number of Asians at Queen Elizabeth Park compared to that of Stanley Park generally reflects the large Asian population in the City of Vancouver. The users of Queen Elizabeth Park who were Whites consisted of $53.56 \%$ while $34.47 \%$ were Asians. Minority racial groups such as Blacks, Aboriginals, Latinos and Multi-Racial group represented $1.99 \%$, I.42\%, $5.41 \%$ and $3.13 \%$ respectively.

\subsection{Income status of park users}

The availability of financial resources allows access to paid leisure activities; increase the ability to purchase transportation and equipment used for leisure activities (Arnord \& Shine, 1998). Arnord and Shinew (1998) further argue that the poor are receiving less leisure appointments due to the rising costs of providing basic leisure services. The income status of park users is therefore a major contributory factor to the use of parks. In the case of tourist parks such Stanley Park, high income earners will have the ability to travel and visit these parks more often than low income earners.

On the other hand, the visitors of neighbourhood parks such as Queen Elizabeth Park must have the ability to afford the purchase of required recreational equipment before they can enjoy leisure activities such as tennis, hockey, golf and basketball. This generally explains the reason why there are more high income earners among the visitors of both Stanley Park and Queen Elizabeth Park. The survey results showed that $32.89 \%$ of the users of Stanley Park earned more than $\$ 100,000$ a year while $24.22 \%$ of the Queen Elizabeth park users earned more than $\$ 100,000$ per year. Also, the findings of the study indicated that $8.49 \%$ of the visitors of Stanley Park earn less than $\$ 15,000$ with park users earning $\$ 15,000-\$ 25,000$ constituting 7.16\%. Furthermore, Stanley Park users who earn $\$ 25,000-\$ 50,000, \$ 50,000-\$ 75,000$ and $\$ 75,000-\$ 100,000$ represented $17.24 \%, 16.45 \%$ and $17.77 \%$ respectively. The study also showed that $9.12 \%$ of the users of Queen Elizabeth Park earn less than $\$ 15,000$. Also, Queen Elizabeth Park users who earn $\$ 15,000-\$ 25,000, \$ 25,000-\$ 50,000$ and $\$ 75,000-\$ 100,000$ comprises of $10.54 \%, 21.37 \%$ and $17.38 \%$ respectively.

\subsection{Place of origin of park users}

Parks are important sites for environmental, economic and social activities, but few studies have documented the behaviour of park users (Kaczynski, 20l I). Parks can either be used by city residents for recreation or by tourist for tourism purposes. The study of the place of origin of park users helps to understand the geographic impact of parks and their overall impact on the economy of the city. Urban parks with wider geographic impact contribute more to the economy of cities, as they help in the promotion of tourism. Stanley Park for instance has a wider geographic impact because majority of the park users representing $34.93 \%$ visited the park from outside Canada. The survey also indicated that $16 \%$ of the users of Stanley Park were from within Canada while $7.2 \%$ were from within British Columbia but outside the City of Vancouver.

All these users were tourists from either within Canada or outside Canada who visited Stanley Park to enjoy the unique environmental setting and recreational facilities. Parks 
such as Stanley Park which promotes tourism contributes immensely to the economy of cities. Cities such as Vancouver generate revenue from park tourists through taxes on goods and services purchased. The various forms of expenditure made by tourists such as expenditure on food, accommodation and transportation contribute immensely towards the expansion of the city's economy. The users of Stanley Park who live in the City of Vancouver and Metro Vancouver consist of $29.87 \%$ and $12.00 \%$ respectively.

Unlike Stanley Park, majority of the users of Queen Elizabeth Park representing $68.95 \%$ visited the park from the City of Vancouver. This therefore makes Queen Elizabeth Park more of a neighbourhood park with less geographic impact compared to Stanley Park. The visitors of Queen Elizabeth Park who come to the park from outside and within Canada were $9.12 \%$ and $5.41 \%$ respectively. The study also showed that the users who visited Queen Elizabeth Park from Metro Vancouver were I I.40\% of the survey population.

\subsection{Distance travelled to visit parks}

Park visitation is more frequent for those who live within walking distance to a park (McCormark et al, 20I0). The proximity to parks influences the frequency and level of park usage. Park users who are normally tourists prefer to live in hotel and hostel facilities that are close to the parks they intend to visit. Stanley Park being one of the major tourist sites in the city of Vancouver has a variety of hotels located within walking distance. The minimum distance travelled to visit Stanley Park was I kilometre. The maximum distance on the other hand was 96 kilometres while the average distance is I3.8 kilometres. The standard deviation is higher than the mean because there were outliers that deviate from the mean. This also explains the wide gap between the minimum and maximum distance travelled to visit the park.

The minimum distance travelled to visit Queen Elizabeth Park is I km and the maximum distance was about 150 kilometers. On average, park users travelled about 20.6 kilometers to visit Queen Elizabeth Park. The results indicated that park visitors were willing to travel more distance to parks that have certain facilities and activities that are not present on the nearby neighbourhood parks. Queen Elizabeth Park for instance has a variety of recreational facilities and also have an off leash park for dogs that are not available in most neighbourhood parks. Table 6.6.10.I presents the distance travelled to visit Stanley Park and Queen Elizabeth Park.

\subsection{Frequency of visit to parks}

The frequency of visit to parks is not only influenced by proximity to the park but also weather conditions. Overall, the survey results indicated that a higher proportion of the users of Stanley Park and Queen Elizabeth Park visited the parks during the summer seasons. The results showed that $2.15 \%$ of the survey respondents visit Stanley Park every day while $68.09 \%$ visit the park during the summer. Also, $10.99 \%$ of the visitors of Stanley Park use the park a few times per week while $6.70 \%$ use the park once a week.

Additionally, Stanley Park users who visit the park once a month or few times per month constituted of $6.17 \%$ and $5.89 \%$ respectively.

On the other hand, park users who visit Queen Elizabeth Park every day were $5.69 \%$ while park users who visit Queen Elizabeth Park during the summer seasons were $48.43 \%$. The survey results also showed that $17.09 \%$ of Queen Elizabeth Park users visit the park a few times a week. Furthermore, the users of Queen Elizabeth Park who visit 
the park once a week, once a month and a few times per month constitute $7.69 \%, 9.12 \%$ and $11.97 \%$ respectively.

\subsection{Funding sources for the development of parks}

Park users' perceptions on how to raise financial resources for the management and maintenance of parks is crucial to the park management decision making process. The historical analysis of parks in the City of Vancouver indicated that park development was historically funded through donations. However, the survey shows that park users are currently not willing to pay for the use of parks but rather expect park development to be funded by the City of Vancouver and other levels of government. The survey indicated that $37.22 \%$ of Stanley Park users expect the City of Vancouver to provide financial resources for the development and management of parks. Also, 14.43\% of the visitors of Stanley Park expect the management and development of parks to be funded by Metro Vancouver while $20.17 \%$ think financial support for park development should come from the Provincial Government. Additionally, Stanley Park users who recommend that the development and management of parks should be funded by the Federal Government, through user fees and donations constitute $14.43 \%, 6.09 \%$ and $7.65 \%$ respectively. The results further indicated that $47.26 \%$ of Queen Elizabeth Park users expect the development and management of the park to be funded by the City of Vancouver. Furthermore, park users who believe funding should be generated from user fees and donations were 3.54\% and 6.37\% respectively. Additionally, Queen Elizabeth Park users who expect Metro Vancouver, the Provincial and Federal Government to fund the development of parks consists of $12.57 \%, 20.53 \%$ and $9.73 \%$ respectively.

\section{I0 Means of transport to parks}

An analysis of the means by which park users visit the parks, help in understanding the overall contribution of the park to carbon foot print and physical activities such as walking. The users of both Stanley Park and Queen Elizabeth Park heavily rely on the use of automobile as the main means of transport to the parks. This increases the level of carbon emissions thus distracting the functional role of parks as a means of preserving the environment. The survey results showed that $41.32 \%$ of the users of Stanley Park visit the park with their private cars while $25.26 \%$ use public transit. Also, park users who visit Stanley Park through cycling and walking were $8.16 \%$ and $21.32 \%$ respectively. Furthermore, Stanley Park users who come to the park by charter bus and taxis consist of $1.58 \%$ and $2.37 \%$ respectively.

Similar to Stanley Park, majority of Queen Elizabeth Park users visit the park using their private cars. The users of Queen Elizabeth Park who visit the park with their private cars constitute $54.79 \%$ while $17.81 \%$ walk to the park. Also, Queen Elizabeth Park users who come to the park by public transit, charter bus, taxi and bicycle represent $20.55 \%, 1.10 \%$, $0.55 \%$ and $5.21 \%$ respectively. The transit system to Stanley Park is more efficient than that of Queen Elizabeth Park. This explains why more users of Stanley Park (25.26\%) rely on public transit than the users of Queen Elizabeth Park (20.55\%).

\section{I I Major concerns on the use on the parks}

The issues of safety and poor park conditions resulting from poor park maintenance deter park use (McCormark et al., 2010). This serves as a justification on the need for park 
administrators to address the major concerns of park visitors to help improve park based activities. The assessment of some of the major areas of concern confronting the use of parks from the perspective of the park users will help inform park decision makers. The major issues raised by the users of Stanley Park and Queen Elizabeth Park were related to issues of maintenance and safety. It is therefore important for the managers of these two parks to develop a maintenance plan in consultation with the park users to help improve these two areas of concern. This is because addressing issues of safety and park maintenance will help improve park conditions and facilitate higher physical activity level. The visitors of Stanley Park who saw the issue of safety as a major area of concern were $18.38 \%$ while $19.42 \%$ were concerned about maintenance. Also, Stanley Park users who expressed concerns about park design and variability of activities consisted of II.I7 $\%$ and $17.01 \%$ respectively. The other concerns expressed by the visitors of Stanley Park were issues of lighting accounting for $4.81 \%$ and availability of transportation options representing $12.20 \%$. Furthermore, park users who had no concern on the current state of Stanley Park constituted 17.01\%.

Additionally, Queen Elizabeth Park users who had issues with safety and maintenance consisted of $16.30 \%$ and $25.00 \%$ respectively. The survey results also showed that Queen Elizabeth Park users who expressed concerns about park design and variability of activities were $14.00 \%$ and $13.00 \%$ respectively. Furthermore, visitors of Queen Elizabeth Park who had issues with lighting and transportation options consisted of $6.16 \%$ and $7.43 \%$ respectively. Finally, the users of Queen Elizabeth Park who were satisfied with the current state of the park were $19.00 \%$.

\section{I 2 Wi-Fi access within parks}

The level of technological advancement has adversely affected the willingness of the youthful population to move away from the cyber space to utilise park space.

Technological advancement has created several indoor entertainment options thus adversely affecting the number of people who are willing to go out and use parks. It is therefore important for park managers to consider combining technological space and park space to maximize the use of parks.

There is currently a proposal to provide Wi-Fi hotspots in 150 locations on Canadian National Parks (CBC, April 29, 20I4). In 2005, the Vancouver City Council considered providing $\mathrm{Wi}-\mathrm{Fi}$ in public places but the implementation of the proposed policy was inhibited by the limited financial resources (CBC, September I4, 20I I). The decision making process on providing accessibility to $\mathrm{Wi}-\mathrm{Fi}$ in parks cannot be sustainable without knowing the views of park users.

The findings of the study showed that park users who want Wi-Fi access on Stanley Park comprised of $51.80 \%$ of the survey respondents while $48.20 \%$ opposed the provision of $\mathrm{Wi}-\mathrm{Fi}$ on the Park. Generally, park users who were in favour of providing accessibility to Wi-Fi cited reasons such as improvement in communication, taking pictures and uploading on social media while using the park, combining leisure and learning. Queen Elizabeth Park users who were in favour of the provision of Wi-Fi were $53.16 \%$ while $46.84 \%$ of the park users opposed the idea. The reasons cited by the park users for opposing the provision of $\mathrm{Wi}-\mathrm{Fi}$ include the interference with nature and the fact that they already have internet data on their mobile phones. 
4. I 3 Benefits derived from the use of Stanley Park and Queen Elizabeth Park

According to McCormack (2010), social and physical environment is a major determinant of park based activities and the direction of influence may be negative or positive. Some of the positive attributes of parks include its natural features such as trees, gardens, flowers and water. These positive features of parks contribute enormously towards the development of cities. The multiple benefits derived from the use of parks vary from economic, social to environmental.

Generally, the multi-functional roles of parks lead to their multi-dimensional benefits. The multiple uses of parks make them a multifunctional landscape. Yang et al. (2013) defines multifunctional landscapes as landscapes designed for multidimensional benefits.

According to the findings of the study, the benefits of Stanley Park and Queen Elizabeth Park as cited by park users were mostly direct benefits. The visitors of the parks did not talk about indirect benefits such as parks serving as storm water management facilities, increasing the tax base of the city through tourism and purifying the air in the city. This notwithstanding, park users gave an extensive overview of the benefits of the parks thus helping to justify some of the already existing literature on the multifunctional benefits of parks. Park users cited various benefits they derive from the use of Stanley Park and Queen Elizabeth Park. These benefits have been grouped in to twelve main categories and further categorised into either economic benefits, social benefits or environmental benefits. Table 3 presents a summary of the benefits park users derive from the use of Stanley and Queen Elizabeth Park.

Table 3. Benefits of using Stanley Park and Queen Elizabeth Park Source: Stanley Park and Queen Elizabeth Park survey, 20I 4

\begin{tabular}{l|l|l|l}
\hline Park Benefit & Category of Benefit & $\begin{array}{l}\text { Stanley Park- } \\
\text { Frequency \% }\end{array}$ & $\begin{array}{l}\text { Queen Elizabeth } \\
\text { Park -Frequency \% }\end{array}$ \\
\hline $\begin{array}{l}\text { Adult and Children } \\
\text { Recreation }\end{array}$ & Social Benefits & 24 & 20 \\
\hline Connection to Nature & Environmental Benefits & 16 & 17 \\
\hline Access to Fresh Air & Environmental Benefits & 4 & 3 \\
\hline Aesthetics & Environmental Benefits & 14 & 15 \\
\hline Dog Recreation & Social Benefits & 1 & 6 \\
\hline $\begin{array}{l}\text { Relaxation and Social } \\
\text { Interaction }\end{array}$ & Social Benefits & 8 & 16 \\
\hline Reflection/Peace/Joy & Social Benefits & 10 & 7 \\
\hline
\end{tabular}

62 | The Journal of Public Space, 3(3), 20I8 | ISSN 2206-9658

City Space Architecture / UN-Habitat 


\begin{tabular}{l|l|l|l}
\hline Exercise/Health & Social Benefits & 13 & 9 \\
\hline Education & Social Benefits & 3 & 4 \\
\hline Tourist Attraction & Economic Benefits & 5 & 2 \\
\hline Employment & Economic Benefits & 2 & 1 \\
\hline
\end{tabular}

4. I The Conflicting and complimentary roles of Parks-Stanley Park and Queen Elizabeth Park Overall, this study showed a continuous increase in the area of concrete surfaces, hard landscaping and the number of physical structures on both Stanley Park and Queen Elizabeth Park. This is as a result of the development of parking lots, tarred roads and paved areas to meet the diversified but conflicting need of park users.

The construction of the Vancouver Aquarium which was opened on June 15, 1956 for example contributed to the increase in paved concrete areas and physical structures on Stanley Park. The Vancouver Aquarium covers an area of about 100,000 square feet. In as much as these concrete surfaces, tarred roads and physical structures have contributed immensely to the stimulation of human activities on the parks, it has also adversely affected their natural characteristics.

There has also been an increase in the amount of storm water generated by the parks while reducing the amount of storm water absorbed. The presence of these physical structures and hard landscaping has therefore helped in improving the social functions of the parks but has adversely affected and limited the environmental functions.

In summary, the research findings indicate that the three main functional roles of parks namely the social, environmental and economic complement each other while these three roles also conflict with each other. Therefore, the maximization of one role can adversely affect the functions of the other. Figure 3 below shows some of the hard landscaping, concrete surfaces, paved roads and physical structures on Stanley Park.

The study also showed that the increase in human activities on Stanley Park and Queen Elizabeth Park have adversely affected the mobility of natural habitats. The movement of natural habitats such as ducks is restricted in the afternoons especially when the level of human activities intensifies. An observational analysis undertaken during the field visits indicated that the ducks on Stanley Park for instance normally come out early in the morning. They however go back to their ponds and the other water bodies around the park during the day time when human activity intensifies. This clearly shows a conflict between natural habitat and human activities on the park. Figure 4 gives pictorial representation of the effects of human activities on the activities of ducks in Stanley Park in the morning and at midday.

Despite the conflict between the economic, social and environmental functions of parks, both Stanley Park and Queen Elizabeth Park continue to perform these multifunctional roles. Stanley Park currently serves as one of the largest tourist destinations in Canada. This helps to promote economic growth through the money spent by tourists in the City 
Relationship between the demographic characteristics of park users and intensity of park use

of Vancouver. The park also serves as nature reserve and at the same time as a place for recreational activities such as cycling, jogging and playing tennis. Figure 5 shows some of the multifunctional roles of Stanley Park.
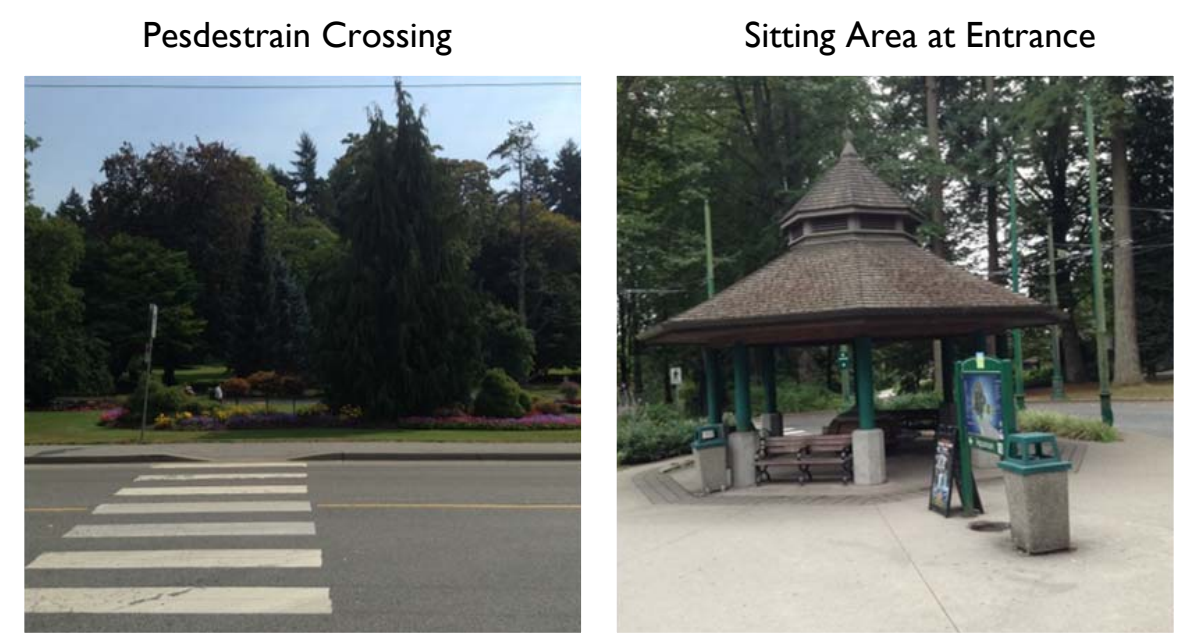

Playground Area
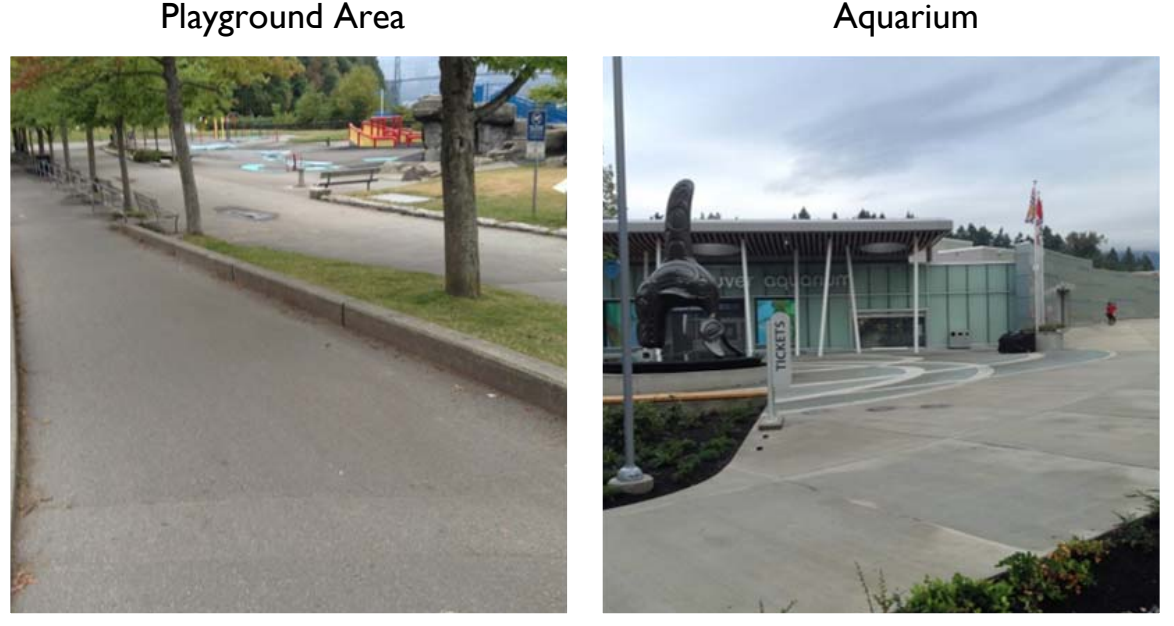

Figure 3. Concrete Landscaping on Stanley Park

Source: Stanley Park and Queen Elizabeth Park Survey, 2014

Queen Elizabeth Park also combines its multifunctional role of promoting environmental preservation, social interaction and economic activities. The park currently serves as a nature reserve with its beautiful quarry garden and greeneries. Social interactions and activities are promoted on the park through the provision of recreational facilities such as basketball courts, tennis court and roller hockey court. The Bloedel Conservatory does not only serve as a tourist attraction but also serves as an educational resource. The park also provides recreation for children through its beautiful fountain. The off leash dog park is an important space for dog recreation. Figure 6 shows some of the multifunctional activities undertaken in Queen Elizabeth Park. 

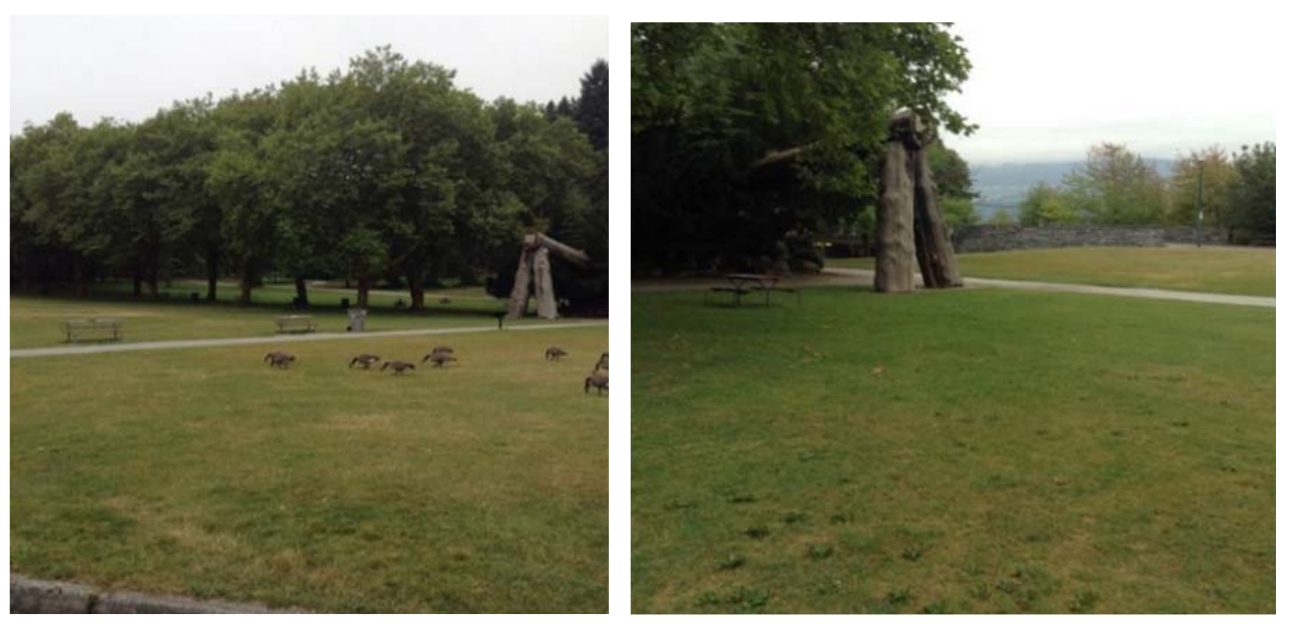

Ducks out at 6am

Ducks gone at midday
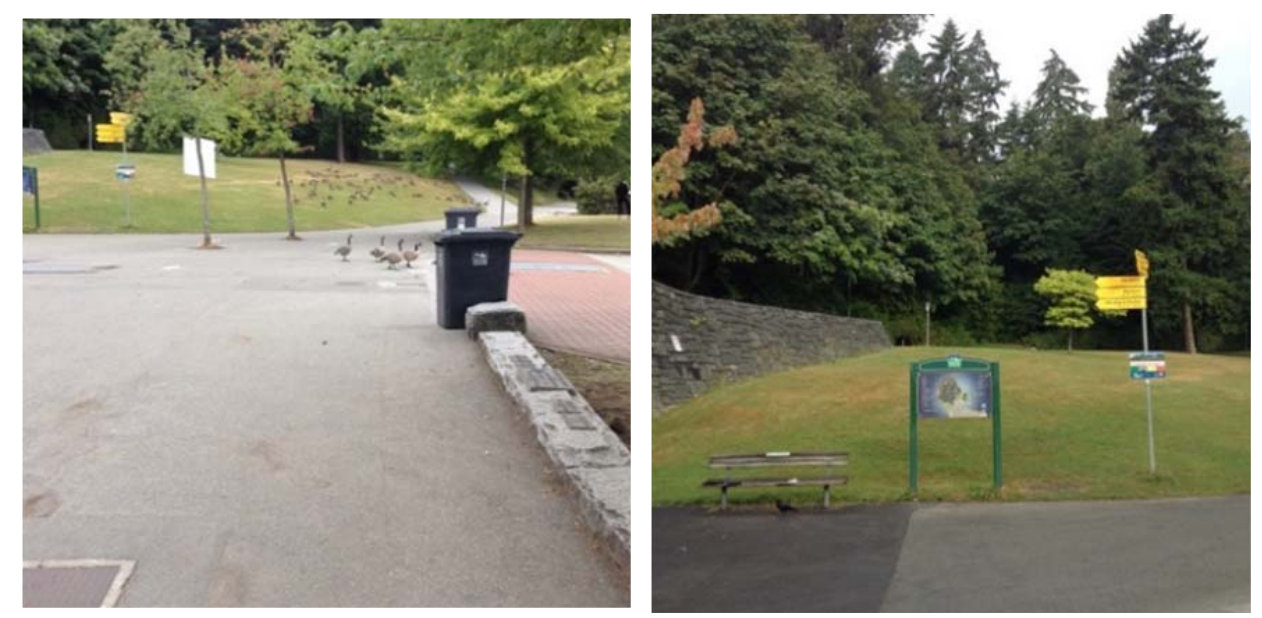

Figure 4. Relationship between Human Activities and Movement of Ducks on Stanley Park Source: Stanley Park and Queen Elizabeth Park Survey, 2014

\section{I5 Demographic characteristics and intensity of park use}

There is the need for park researchers and administrators to understand the relationship between the demographic characteristics of park users and the intensity of park use. This will help inform decision makers on the demographic characteristics to consider when promoting specific park based activities. The statistical analysis showed that there is no significant relationship between employment, marital status, gender, race, religion, income and intensity of Stanley Park use $(P>0.05)$. There is therefore not enough evidence to suggest that the null hypothesis $\left(H_{0}\right.$ : there is no relationship between employment, marital status, gender, race, religion, income and intensity of Stanley Park use) is false at $95 \%$ confidence level. However, the chi-square analysis showed a statistically significant 
Relationship between the demographic characteristics of park users and intensity of park use

relationship between place of origin, age and intensity of Stanley Park use ( $P \leq 0.05)$. Hence, there is enough evidence to suggest that the null hypothesis is false at $95 \%$ confidence level. The survey results indicated that park users from Vancouver are more likely to use Stanley Park at a higher intensity rate than park users from outside Canada. The statistical analysis indicated that $68.59 \%$ of the park users who came from Vancouver use Stanley Park at higher intensity rate compared to $39.23 \%$ among park users from outside Canada.

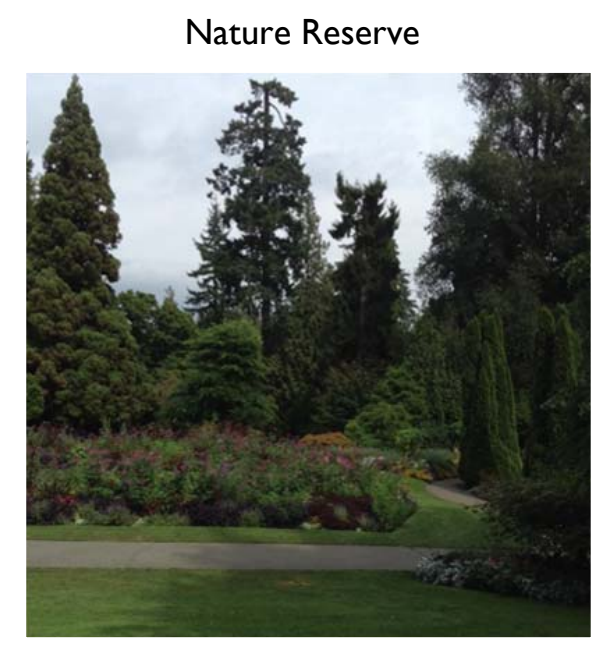

Tennis Court

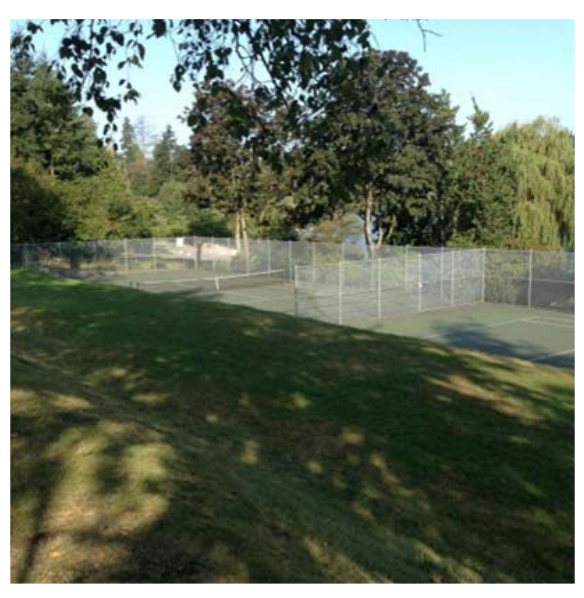

Figure 5 (bottom). Multifunctional Roles of Stanley Park

Source: Stanley Park and Queen Elizabeth Park Survey, 2014

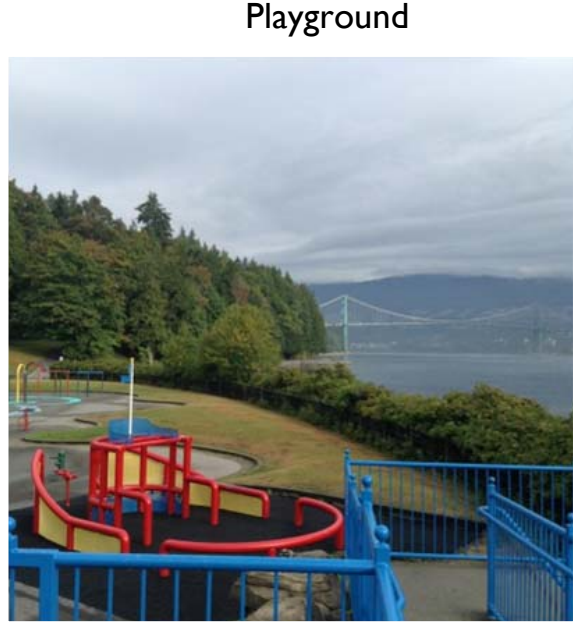

Sitting Area Along Bike Lanes

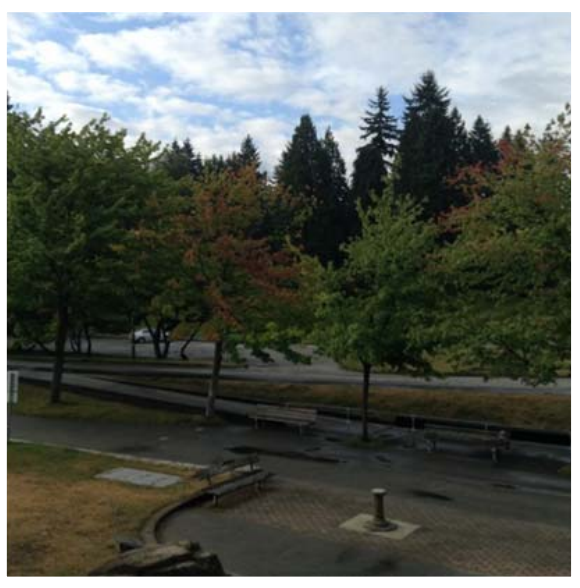




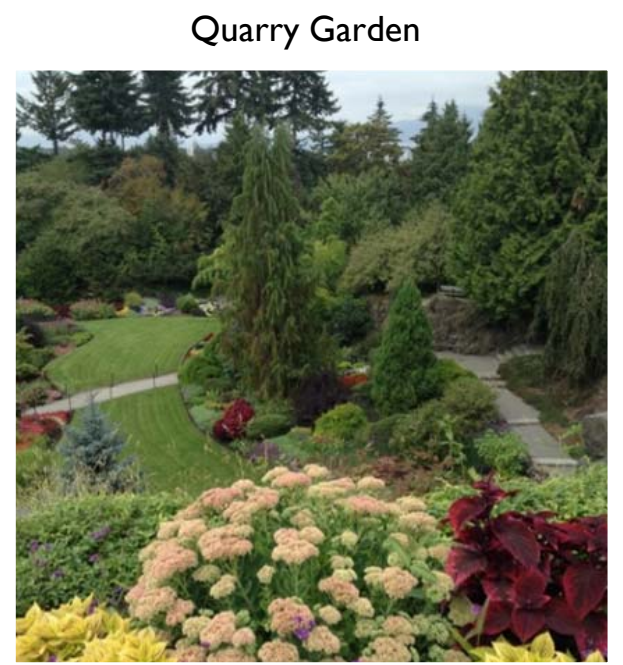

Tennis Court

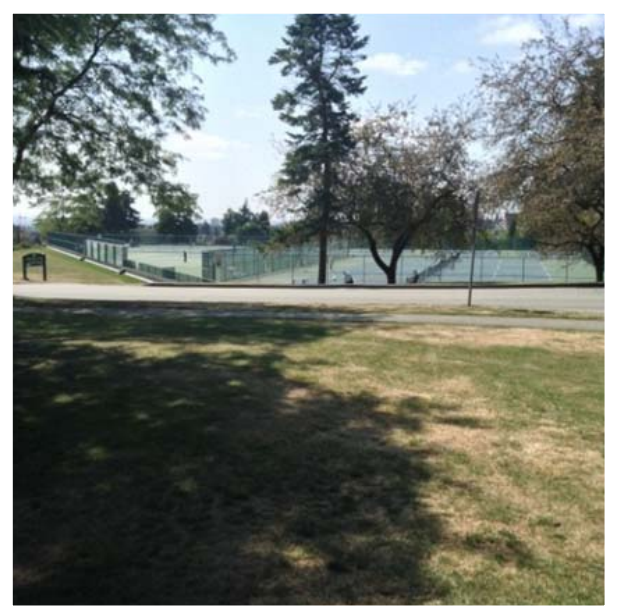

Bloedel Conservatory



Fountain

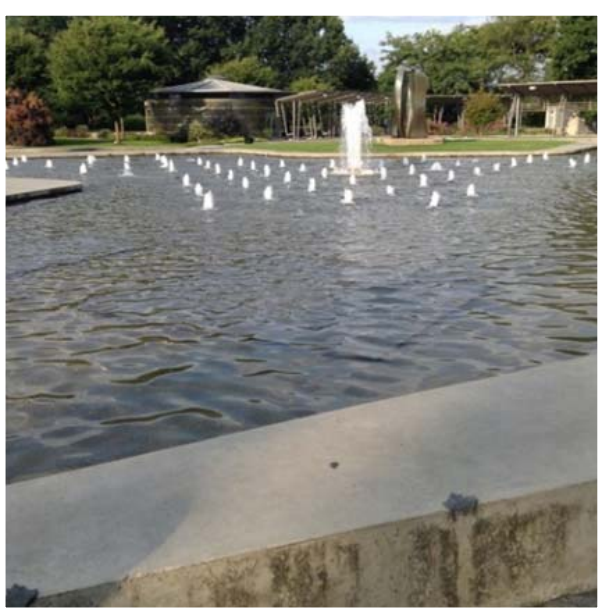

Figure 6. Multifunctional Roles of Queen Elizabeth Park Source: Stanley Park and Queen Elizabeth Park Survey, 2014

Overall, the statistical analysis showed that the intensity of Stanley Park use is higher among park visitors who came from Vancouver (68.59\%) than park users who came from outside Canada (39.23\%). Also, park users below the age of 30 years are more likely to use Stanley Park at a higher intensity rate than park users who are above the age of $\mathbf{4 0}$ years. The survey results indicated that $54.13 \%$ of the park users who are below the age of 30 years use Stanley Park at a higher intensity rate whilst it is $46.50 \%$ among park users above the age of 40 years. Table 4 shows the summary of the bivariate analysis of demographic characteristics and intensity of Stanley Park use. 
Relationship between the demographic characteristics of park users and intensity of park use

Table 4. Analysis of Demographic Characteristics and Intensity of Stanley Park Use

\begin{tabular}{|c|c|c|c|c|}
\hline & \multicolumn{2}{|c|}{$\begin{array}{c}\text { Intensity } \\
(\%)\end{array}$} & \multirow[b]{2}{*}{ X2 Test } & \multirow[b]{2}{*}{ P-Value } \\
\hline & Low & High & & \\
\hline Employment & & & 0.07 & 0.797 \\
\hline Fulltime & 46.19 & 53.81 & & \\
\hline Other & 47.53 & 52.47 & & \\
\hline Marital status & & & 2.99 & 0.084 \\
\hline Married & 51.04 & 48.96 & & \\
\hline Other & 41.92 & 58.08 & & \\
\hline Sex & & & 0.49 & 0.485 \\
\hline Male & 48.65 & 51.35 & & \\
\hline Female & 45.00 & 55.00 & & \\
\hline Place of origin & & & 26.85 & 0.000 \\
\hline Vancouver/Metro Van & 31.41 & 68.59 & & \\
\hline Within Canada & 54.12 & 45.88 & & \\
\hline Outside Canada & 60.77 & 39.23 & & \\
\hline Race & & & 2.82 & 0.093 \\
\hline White & 50.00 & 50.00 & & \\
\hline Ethnic Minority & 40.80 & 59.20 & & \\
\hline Religion & & & 0.74 & 0.690 \\
\hline Christians & 48.62 & 51.38 & & \\
\hline Other Religion & 48.65 & 51.35 & & \\
\hline No Religion & 44.08 & 55.92 & & \\
\hline Income & & & 0.0002 & 0.989 \\
\hline Under $\$ 50,000$ & 46.72 & 53.28 & & \\
\hline Over $\$ 50,000$ & 46.80 & 53.20 & & \\
\hline Age & & & 6.48 & 0.039 \\
\hline Under 30 & 45.87 & 54.13 & & \\
\hline $30-40$ & 37.50 & 62.50 & & \\
\hline Over 40 & 53.50 & 46.50 & & \\
\hline
\end{tabular}

* $\mathrm{H}_{\mathrm{o}}$ : There is no relationship between the demographic characteristics of park users and intensity of Stanley Park Use

* Ha: There is a relationship between the demographic characteristics of park users and intensity of Stanley Park Use 
The statistical analysis indicated that there is no significant relationship between marital status, race, income, age and the intensity of Queen Elizabeth Park use ( $P>0.05)$.

Therefore, there is not enough evidence to suggest that the null hypothesis is false at $95 \%$ confidence level.

On the other hand, there is a statistically significant relationship between employment, gender, place of origin, religion and the intensity of Queen Elizabeth Park use ( $\mathrm{P} \leq 0.05)$.

Consequently, there is enough evidence to suggest that the null hypothesis (is false at $95 \%$ confidence level.

In terms of employment, park users who are full time employed (59.88\%) tend to use Queen Elizabeth Park at a high intensity rate than the aggregate of park visitors who belong to other employment categories such as students, unemployed, retired and seasonally employed (47.54\%). The findings of the study further showed that males (58.56\%) use Queen Elizabeth Park at a higher intensity rate than females (47.59\%). Additionally, the intensity of Queen Elizabeth Park use among park visitors who came from Vancouver $(56.79 \%)$ is higher than the intensity of use among park users who came from outside Canada (40.63\%). The statistical analysis further indicated that park users who belong to other religions such as Buddhism (63.04\%) use Queen Elizabeth Park at a higher intensity rate than park users who are Christians (44.92\%) and park visitors who are not affiliated to any other religion (56.22\%).

In as much as there is no significant relationship between age and Queen Elizabeth Park use, the statistical analysis showed that park users below the age of 30 years (53.08\%) use the park at a higher intensity rate than the users above the age of 40 years (48.98\%).

Table 5 shows the bivariate analysis of demographic characteristics and intensity of Queen Elizabeth Park use.

Table 5. Analysis of Demographic Characteristics and Intensity of Queen Elizabeth Park Use

\begin{tabular}{|c|c|c|c|c|}
\hline & \multicolumn{2}{|c|}{ Intensity (\%) } & \multirow[b]{2}{*}{$x^{2}$ Test } & \multirow[b]{2}{*}{ P-Value } \\
\hline & Low & High & & \\
\hline Employment & & & 5.34 & 0.021 \\
\hline Fulltime & 40.12 & 59.88 & & \\
\hline Other & 52.46 & 47.54 & & \\
\hline Marital status & & & 1.54 & 0.215 \\
\hline Married & 50.33 & 49.67 & & \\
\hline Other & 43.65 & 56.35 & & \\
\hline Sex & & & 4.189 & 0.041 \\
\hline Male & 41.44 & 58.56 & & \\
\hline Female & 52.41 & 47.59 & & \\
\hline Place of origin & & & 5.85 & 0.054 \\
\hline Vancouver/Metro Van & 43.21 & 56.79 & & \\
\hline Within Canada & 59.46 & 40.54 & & \\
\hline Outside Canada & 59.38 & 40.63 & & \\
\hline Race & & & 0.52 & 0.473 \\
\hline White & 44.62 & 55.38 & & \\
\hline
\end{tabular}


Relationship between the demographic characteristics of park users and intensity of park use

\begin{tabular}{lllll}
$\begin{array}{l}\text { Ethnic Minority } \\
\text { Religion }\end{array}$ & 48.47 & 51.53 & 5.72 & 0.057 \\
$\quad$ Christians & 55.08 & 44.92 & & \\
Other Religion & 36.96 & 63.04 & & \\
No Religion & 43.78 & 56.22 & & \\
Income & & & 1.16 & 0.282 \\
Under $\$ 50,000$ & 50.00 & 50.00 & & \\
Over $\$ 50,000$ & 44.17 & 55.83 & & \\
Age & & & 3.87 & 0.144 \\
Under 30 & 46.92 & 53.08 & & \\
$30-40$ & 36.99 & 63.01 & & \\
Over 40 & 51.02 & 48.98 & & \\
\hline
\end{tabular}

* $\mathrm{H}_{\circ}$ : There is no relationship between the demographic characteristics of park users and intensity of Stanley Park Use

* Ha: There is a relationship between the demographic characteristics of park users and intensity of Stanley Park Use

\subsection{Discussion and conclusion}

Veitch et al. (2014) believe that modifying the built environment by improving parks is a sustainable way to increase population level social, activities. The demographic characteristics of park users are important determinants in the use and management of parks. The results of the study indicated that the use of both Stanley Park and Queen Elizabeth Park are dominated by the youthful population with an average age of 40 years and 39 years respectively. Mowen et al. (2012) for example justify this results by arguing that older adults are less active compared to younger adults thus, they are less likely to dominate in the use of parks.

The findings of the research also showed that more males use Stanley Park and Queen Elizabeth Park compared to their female counterparts. Generally, this results did not deviate from studies done by park researchers such as Arnold and Shinew (1998), Kaczynski et al. (20I I) and Henderson et al. (1996). There researchers believe that women are among one of the disadvantaged when it comes to the use of parks. Therefore, there is the need for park administrators and policy makers to promote safety on parks in order to stimulate park use by women.

In terms of the employment status of the park users, the study showed a high employment rate among the visitors of both Stanley Park and Queen Elizabeth Park. This also justifies the theoretical standpoint that people with higher employment status tend to use parks and other leisure spaces at a higher rate. Park researchers such as Kelly (I987) believe that there is a positive association between higher occupational statuses and leisure participation.

According to Statistics Canada (20I5), the unemployment rate for the City of Vancouver in 2014 was $5.20 \%$ and that of 2015 is $4.80 \%$. Generally, the unemployment rate for City of Vancouver in 2014 and 2015 is higher than the unemployment rate for users of Stanley Park (4.68\%) and Queen Elizabeth Park (3.91\%). Arnord and Shinew (1998) argue that the 
poor are receiving less leisure appointments due to the rising costs of providing basic leisure services. The income status of park users is therefore a major contributory factor to the use of parks.

In the case of tourist parks such Stanley Park, high income earners will have the ability to travel and visit these parks more often than low income earners. On the other hand, the visitors of neighbourhood parks such as Queen Elizabeth Park must have the ability to afford the purchase of required recreational equipment before they can enjoy leisure activities such as tennis, hockey, golf and basketball. This generally explains the reason why there are more high income earners among the visitors of both Stanley Park and Queen Elizabeth Park.

The survey which did not contradict some of the already existing literature on park use and race revealed that most of the tourists who visited Stanley Park for instance came from Europe thus contributing to the high percentage of Whites. Anold and Shinew (1998) argues that minority ethnic groups such as Blacks are among the disadvantaged categories of people in the United States thus adversely affecting their level of leisure participation. Kaczynski et al. $(20 \mathrm{II})$ also found that a greater percentage of Whites are active park users than other racial groups such as Blacks.

The frequency of visit to parks is not only influenced by proximity to the park but also weather conditions. Overall, the survey results indicated that a higher proportion of the users of Stanley Park and Queen Elizabeth Park visit the parks during the summer seasons.

Generally, there has been a major shift on park users' perceptions on how to raise financial resources for the management and maintenance of parks. The historical analysis of parks in the City of Vancouver indicated that park development was historically funded through donations. However, the survey shows that park users are currently not willing to pay for the use of parks but rather expect park development to be funded by the City of Vancouver and other levels of government. The survey indicated that $37.22 \%$ of Stanley Park users expect the City of Vancouver to provide financial resources for the development and management of parks whilst it is $47.26 \%$ among Queen Elizabeth Park users.

In terms of the means of transport to the parks, the users of both Stanley Park and Queen Elizabeth Park rely heavily on the use of automobile. This increases the level of carbon emissions thus distracting the ecological role of parks as a means of preserving the environment. The survey results showed that $41.32 \%$ of the users of Stanley Park visit the park with their private cars compared to $54.79 \%$ among Queen Elizabeth Park users. This has also increased the demand for parking spaces on the parks. The major concerns of the users of Stanley Park and Queen Elizabeth Park were mostly related to issues of maintenance and safety. It is therefore important for the managers of these two parks to develop a maintenance plan in consultation with the park users to help improve these two areas of concern. This is because addressing issues of safety and park maintenance will help improve park conditions and facilitate higher physical activity levels.

With regard to park users' opinion on the provision of Wi-Fi on the parks, the study showed that park users who want Wi-Fi access on Stanley Park comprised of $51.80 \%$ while $48.20 \%$ opposed the provision of Wi-Fi on the park. Generally, Stanley Park and Queen Elizabeth Park users who were in favour of providing accessibility to Wi-Fi cited reasons such as improvement in communication, taking pictures and uploading on social media while using the park, combining leisure and learning. The reasons cited by the 
visitors of the parks for opposing the provision of Wi-Fi include the interference with nature and the fact that they already have internet data on their mobile phones.

Generally, the research finding indicated that park users who live in Vancouver use both Stanley Park and Queen Elizabeth Park at a higher intensity rate than users coming from outside Canada. This therefore implies that the proximity to parks is an important determinant of the intensity of park use. The chi-square analysis showed a statistically significant relationship between place of origin, age and intensity of Stanley Park use $(P \leq 0.05)$. Hence, there is enough evidence to suggest that the null hypothesis is false at 95\% confidence level. The survey results showed that park users from Vancouver are more likely to use Stanley Park at a higher intensity rate than park users from outside Canada. The statistical analysis indicated that $68.59 \%$ of the park users who came from Vancouver use Stanley Park at higher intensity rate compared to 39.23\% among park users from outside Canada. Overall, the statistical analysis showed that the intensity of Stanley Park use is higher among park visitors who came from Vancouver $(68.59 \%)$ than park users who came from outside Canada (39.23\%). Also, park users below the age of 30 years are more likely to use Stanley Park at a higher intensity rate than park users who are above the age of 40 years. The survey results indicated that $54.13 \%$ of the park users who are below the age of 30 years use Stanley Park at a higher intensity rate whilst it is $46.50 \%$ among park users above the age of 40 years.

Parks are important urban infrastructure used for aesthetic development, promoting social interaction and the preservation of the natural environments of cities. The multifunctional roles of parks is complementary and at the same time conflicting.. These findings will inform policy makers on the demographic characteristics to consider when developing park based programs and facilities. The study shows that different demographic variables influence the intensity in the utilization of Stanley Park and Queen Elizabeth Park. Park administrators and policy makers must therefore undertake park specific needs assessment when providing park facilities, programs and services. This will help promote effective and efficient park service delivery.

\section{References}

Arnold, M.L. \& Shinew, K. L. (1998). The role of gender, race and income on park use constraints, Journal of Park and Recreation Administration, I6(4), 39-56.

Ballard, R. (2002). Race, ethnicity and culture, in Martin Holborn (ed.), New direction in Sociology, Ormskirk: Causeway.

Burdge, R.J. (1969). Levels of occupational prestige and leisure activity, Journal of Leisure Research, I, pp. 262-274.

Byrne, J. \& Sipe, N. (2010). Green and open space planning for urban consolidation: A review of the literature and best practice, Urban Research Program, Issues Paper II, Brisbane, Griffith University.

Calkins, M. (2005). Strategy use and challenges of ecological design in landscape architecture, Landscape and Urban Planning, 73(I), 29-48. 
Cohen, D.A., McKenzie, T.L., Sehgal, A., Williamson, S., Golineli D. \& Lurie N. (2007). Contribution of public parks to physical activity, American Journal of Public Health, 97(3), 509-5I4.

Field, D.R. (2000). Social groups and parks: Leisure behavior in time and space, Journal of Leisure Research, 32(I), 27-3I.

Gobster, P.H. (2002). Managing urban parks for a racially and ethnically diverse clientele, Leisure Sciences: An Interdisciplinary Journal, 24(2), I43-I59.

Henderson, K.A, Bialeschki, M.D. Shaw, S. \& Freysinger, V. (1996). Both gains and gaps: feminist perspective on women's leisure, State College, PA: Venture Publishing.

Home R., Bauer N. \& Hunziker M. (2007). Constructing urban green spaces: An application of Kelly's repertory grid, Tourism Review, 62(4), 47-52.

Horak, M. \& Young, R. (Eds.) Sites of governance, multilevel government and policy making in Canada's big cities, McGill-Queen's University Press, 263-293.

Kaczynski, A. \& Henderson, K. (2007). Environment correlates of physical activity: A review of evidence about parks and recreation, Leisure Sciences, 29, 3I5-354.

Kaczynski, A.T, Stanis, S.A.W., Hastmann, T.J. \& Besnyi, G.M. (20I I): Variations in observed park physical activity intensity level by gender, race and age: individual and joint effects, Journal of Physical Activity and Health, 8(2), I5I-I60.

Kelly, J.R. (1987). Recreation towards the Year 2000, Champaign, IL: Management Learning Laboratories.

Kemperman, D.A.M. \& Timmermans, H. J.P. (2006). Heterogeneity in urban park use of aging visitors: A latent class analysis, leisure sciences, An Interdisciplinary Journal, 28(I), 57- 71.

McCormark, G.R, Rock, M., Toohey, A.M. \& Hignell, D. (2010). Characteristics of urban parks associated with park use and physical activity: A Review of Qualitative Research, Health \& Place, 16, 7I2-726.

Mowen, A.J, Trauntvein, N.E., Graefe A.R. \& Son J.S. (2012). The influence of visitor characteristics on state park physical activity levels, Journal of Park and Recreation Administration, 30(2), 19-40. 
Payne L.L., Mowen, A.J. \& Orsega-Smith, E. (2002). An examination of park preferences and behaviours among urban residents: The role of location, race and age, Leisure Sciences, An Interdisciplinary Journal, 24(2), I8I-I 98.

Sadeghian, M. M., \& Vardanyan, Z. (20I5). A brief review on urban park history, classification and function, International Journal of Scientific \& Technology Research, 4(8), I20-124.

Scott, D. (1997). Exploring time patterns in people's use of A Metropolitan Park District, Leisure Sciences, 19(3), I59-177.

Statistics Canada (2008). Canadian Social Trends (Code II-008-XWE). Released November 2I, 2008. http://www.statcan.gc.ca/pub/II-008-x/2007004/I03 I3-eng (accessed November 8, 2013).

Statistics Canada. (2012). Vancouver, British Columbia (Code 59/5022) and Greater Vancouver, British Columbia (Code 5915) (table). Census Profile. 20II Census. Statistics Canada Catalogue no. 98-316-XWE. Ottawa. Released October 24, 2012. http://wwwl2.statcan.gc.ca/census-recensement/20I I/dp-pd/prof/index.cfm?Lang=E (accessed September 10, 2013).

Sudman, S. (1976). Applied sampling (Quantitative Studies in Social Relations), New York: Academic Press.

Takyi, S. A. (2016). Evolution of park planning in the City of Vancouver. Focus, I2(I), II.

Takyi, S. A., \& Seidel, A. D. (2017). Adaptive management in sustainable park planning and management: case study of the city of Vancouver Parks, Journal of Urban Ecology, 3(I).

Veitch, J, Salmon J., Carver, A., Timperio, A., Crawford, D., Fletcher, E. \& Giles-Corti B. (20I4). A natural experiment to examine the impact of park renewal on park-use and parkbased physical activity in a disadvantaged neighborhood: The REVAMP Study Methods, BMC Public Health, I4(600). DOI: I0.I I86/I47I-2458-I4-600.

Yin, R. K. (2008). Case study research design and methods, ( $4^{\text {th }}$ Ed.), Thousand Oaks: Sage. 